技術ノート

\title{
地球深部探査船「ちきゅう」の物理探査・地質データの活用と今後の期待
}

\author{
木戸 ゆかり ${ }^{1)} \cdot$ 杉原 $_{\text {孝充 }}{ }^{1)} \cdot$ 真田 佳典 $^{1)}$
}

\section{Site Survey and Logging data integration of D/V Chikyu}

\author{
Yukari KIDO ${ }^{1)}$, Takamitsu SUGIHARA ${ }^{1)}$ and Yoshinori SANADA ${ }^{1)}$
}

\begin{abstract}
Since July of 2005, Drilling Vessel (here after D/V) Chikyu has launched and did shakedown cruises to be ready for international operation by developing new and state of the art technologies. From Oct. in 2007, D/V Chikyu started a first Integrated Ocean Drilling Program (IODP) expedition in Nankai Trough. She has been carried out 16 challenging expeditions of Seismogenic Zone of Nankai Trough and Japan Trench, Deep Biosphere off Shimokita and Muroto, Thermal Active zone of Okinawa Trough during these 12 years. Center for Deep Earth Exploration (abbreviated as CDEX) in JAMSTEC (Japan Agency of Marine Science and TEChnology) is one of the three implementing organizations of the International Ocean Discovery Program (recent IODP) and leading scientific drilling operations including site survey, well and mud logging, gas monitoring service to achieve safety drilling. After decade preparation, the first scientific phase of IODP has been successfully done and new IODP seeks dawn horizons of next targets and deeper portion of the earth.
\end{abstract}

Key words : D/V Chikyu, IODP, Site survey, 2D/3D seismic survey, Logging

\section{1.はじめに}

地球深部探査船「ちきゅう」は, 構想から 10 年を経て 建造され，2005年7月29日にJAMSTEC（現在の国立研究 開発法人 海洋研究開発機構) に引き渡された (第 1 図)。2 年間の慣熟航海期間を経て，2007年10月からは，IODP (Integrated Ocean Drilling Program : 統合国際深海掘削計画) の主力船の一隻として, 日本周辺の複数箇所の科学掘削に 実績を残してきた(第2図).

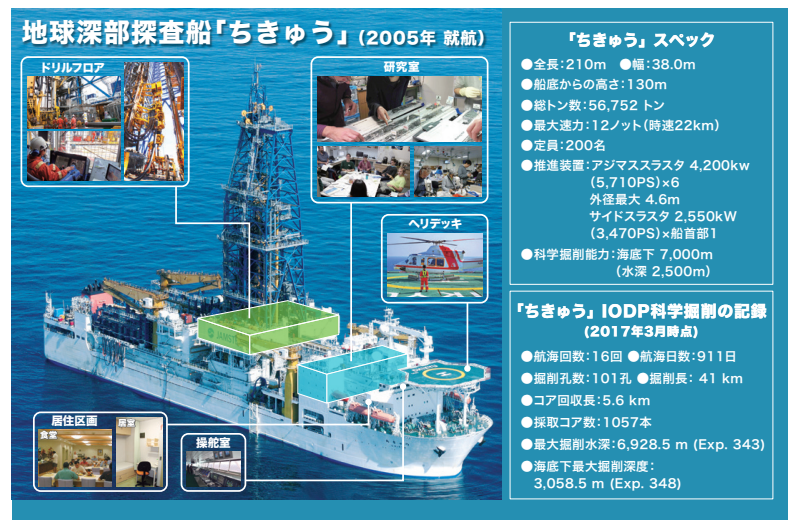

第 1 図＼cjkstart地球深部探査船「ちきゅう」の仕様（2017年 3 月版）
本稿では，情報地質学分野に利用価値が高いと思われる 「ちきゅう」の科学掘削の際の科学支援のうち, 事前準備 や掘削時に得られる地質情報について紹介する.

「ちきゅう」は，2007年10月から国際運航を開始し， 2017 年 11 月現在までにIODPのプロジェクトの枠組み内 で 25 研究航海 (第1および2図) を数え，4つの大きな科 学目標を柱に研究航海を重ねてきた。就航 12 年の間に, 国際深海科学掘削の枠組みや体制は変化しつつも, 米国,

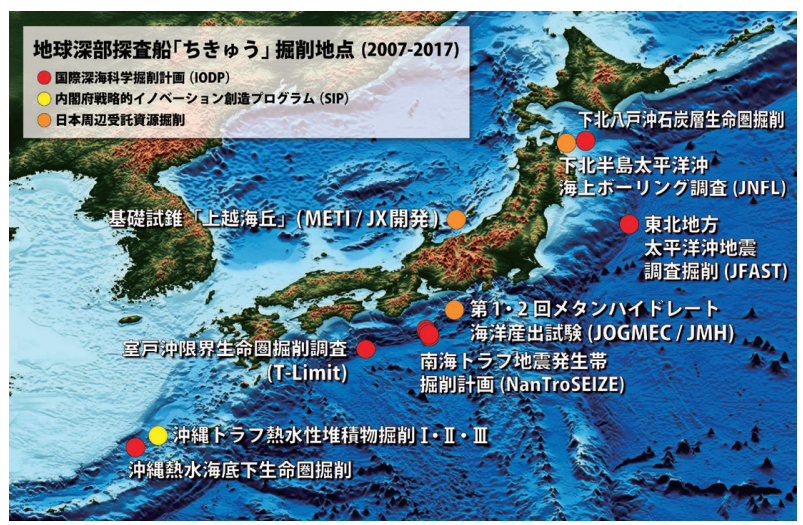

第2図 2007年から 2017 年までの「ちきゅう」による日本周辺の 科学掘削位置情報

2017 年 11 月 10 日受付, 2018 年 1 月 22 日受理

資源・素材学会春季大会 $(2013$ 年 3 月, 開催地 : 千葉工業大学) で一部講演

1) 国立研究開発法人海洋研究開発機構地球深部探査センター Center for Deep Earth Exploration (CDEX), Japan Agency for Marine-Earth Science and Technology, 3173-25 Showa-machi, Kanazawa-ku, Yokohama-shi, Kanagawa 236-0001, Japan. E-mail: ykido@jamstec.go.jp 


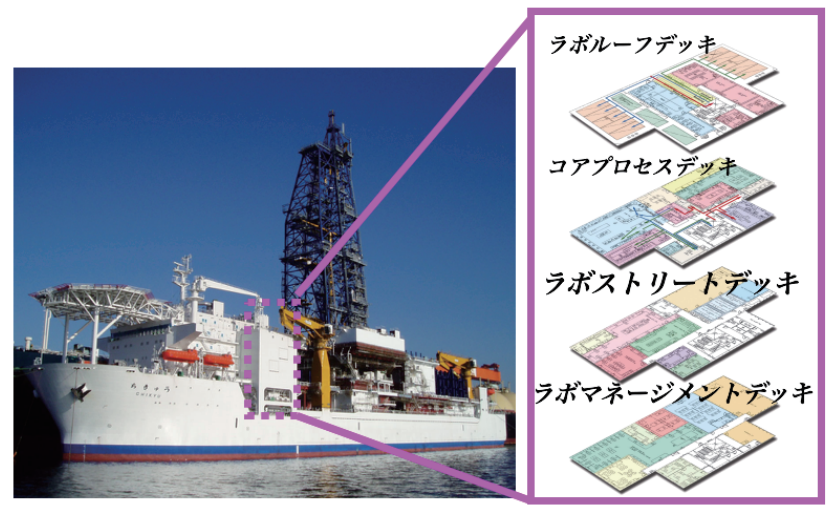

第3図「ちきゅう」実験室

欧州, 日本の三主導による海洋科学掘削が展開されている. 今後の展開に向けての課題や新たな取り組みについても, 言及する。

\section{2.「ちきゅう」の特徵}

「ちきゅう」は，2001年に建造を開始し，2005年に完成 した，水面からの高さ $120 \mathrm{~m}$ の櫓がシンボルである（第 1 図).ライザーシステムという循環系の掘削能力を備えた 世界初の科学掘削船である。風や潮の影響を受けても, 定 位置を保ちながら掘削を続けることができる 6 基のアジマ ススラスターを船底に設置した定点保持システムや船体動 摇センサーを搭載し, 船の上下動を吸収する装置等を取り 入れ，極めて摇れない構造になっている，そのため, 船内 の4階分の実験棟には，X線 CTスキャン装置はじめ, 電 子顕微鏡, 微生物実験器具, 孔内計測や地球化学実験用の 精密機器が多数搭載され, 担当のテクニシャンがそれぞれ 張り付き, 測定精度の高いデータが得られている。精密機 器の数々は, パーティションの切られた様々な分野の実験 室に設置されている (第3図および第 4 図)。例えば，パー マロイの特殊合金でシールドされた古地磁気ラボには, 超 伝導磁力計をはじめとしてスピナー磁力計, 熱・交流消磁 器が設置されている，微生物ラボには嫌気グローブボック スや多目的培養器が設置され, さらに個々の研究者の持 ち込み機材の設置場所も確保されている。「ちきゅう」は, 優れた研究成果を発信する「洋上に浮かぶ研究所」として 設計された。

\section{3.「ちきゅう」運用体制とJ-DESCによる科学支援} 地球深部探査船「ちきゅう」を運用する地球深部探査七 ンター $(\mathrm{CDEX})$ の体制を第 5 図に示す。CDEXは, 我が国 における統合国際深海掘削計画 (IODP) の総合的推進なら びに地球深部探査船「ちきゅう」の運用及び関連する技術 研究開発を行うことが任務とされ，「ちきゆう」を中心と した一元的組織が構築された. IODPでは世界の研究者が 競って提案書を出し, 国際パネル委員会の審査を経て, 優 先順位付けされた後, 実現に向けて運用側と一体となって
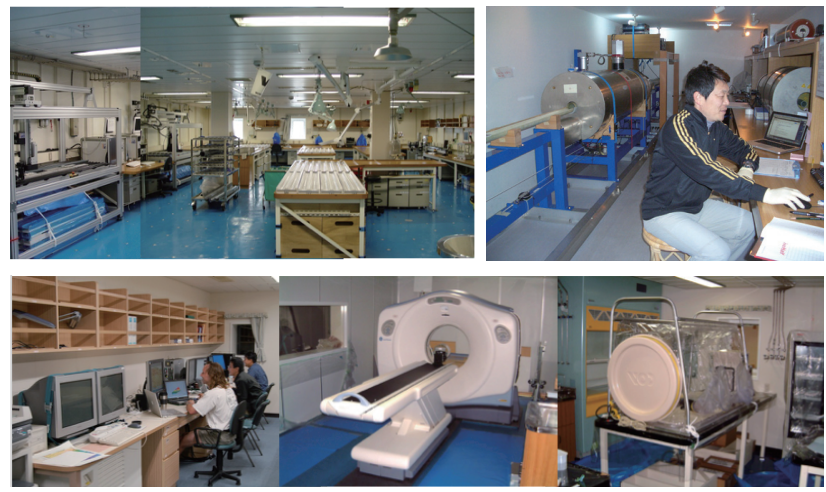

第4図「ちきゅう」実験室の様子, ラボ記載デスク（上左）, 古地 磁気シールドルーム内の超伝導磁力計と熱消磁計(上右), データマネージメント室 (下左), XCTスキャナー (下中), 微生物ラボ内の嫌気グローブボックス（下右）

実施に向かうプロポーザル制をとっている，なお，CDEX 内の組織としては, その後の業務の展開に応じて見直すこ ともあったが, 概ね企画調整, 運用管理, 技術開発, 科学 支援部ならびに独立した環境保安グループによって構成さ れてきた. 現在, 以下に示すような条件・方針のもとで運 用・管理がなされている.

OJAMSTECが保有・運用・管理する日本船籍の船舶とし て，法令を遵守した運用

IODP科学計画の着実な遂行

○安全を第一とした運用

○効率的 (経済的) な運用

○大水深 - 大深度の海洋掘削に関する技術, 知見, ノウハ ウの我が国への蓄積, 向上

○国民に開かれた運用

しかしながら，その実態は，年に1〜2航海を実施す るのがやっとの予算・人材規模であり, 効率的な運用と は言えない.「ちきゅう」という大きなファシリティを広 くコミュニティに知らせる日本国内の空口は, 日本掘削科 学コンソーシアム (Japan Drilling Earth Science Consortium: J-DESCウェブサイト: http://j-desc.org/）が担当している.

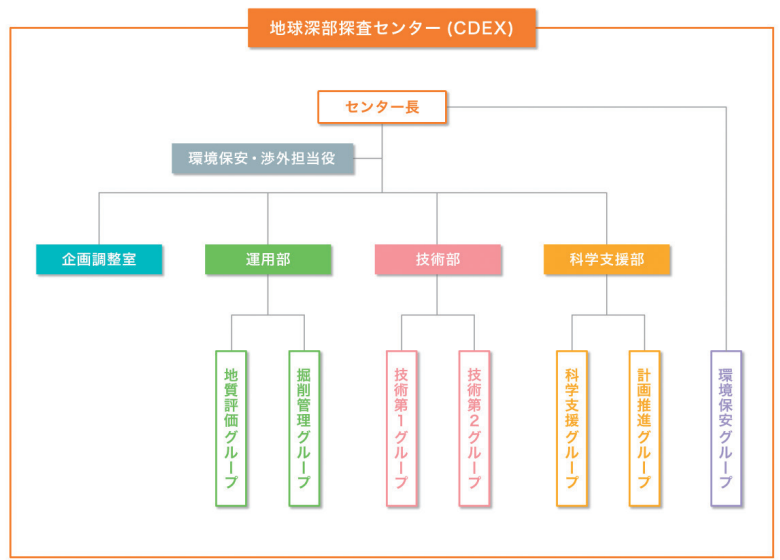

第5図 CDEX (地球深部探査センター) 体制図 (H30 年 1 月現在) 
定期的に科学掘削の動向をメイリングリストやウェブサイ トから発信し, 乗船研究者の募集, 旅費のサポート, 新し いプロポーザルの作成支援，掘削科学関係のスクールを開 き，若手人材育成も働きかける，その組織は，陸上および 海洋掘削の執行部会により支えられている，様々な分野の 研究者が持ち回り制で執行部会に参加し, 掘削科学のあり 方を議論している，低迷する掘削科学を盛り上げるための 大型予算獲得, 人材育成や研究計画, 慢性的な人材不足と いった課題を抱え，次の一歩を踏み出すべく，既存の体制 を打開し，新境地を切り開く瀬戸際に来ている.

\section{4. 掘削事前調査}

地球深部探査センター内の質評価グループが担当する掘 削事前の安全性評価項目は, 海底面の平坦さ, 突起物がな いか, ガスや湧出がないか, 底質の強度があるか, といっ た数項目である (第 1 表)。すなわち, 海底表層地形の精査, AUV (Autonomous Underwater Vehicle) による潜航調査で の高精度海底地形マッピング, サイドスキャン音響画像, サブボトムプロファイラーでのウェルヘッド設置地点選定 のための微地形の把握, 底質の適合性評価, 浅部域の浅層 ガスの有無, 帯水層, 断層分布等の浅層ハザード評価, ウエ ルヘッドやライザートップホール構築のための浅層地質強 度評価, 掘削計画最適化のための地質評価, 深層ハザード 評価, 掘削深度全域にわたる速度構造調査などである.

この 12 年の間,「ちきゅう」科学掘削のメインター ゲットの一つであった南海トラフにおける巨大地震発 生メカニズムを解明するための掘削調査 (Nankai Trough Seismogenic Zone Experimentを略してNanTroSEIZE）に多 くの時間・労力を費やした，その事前調査となる，2 次元 3 次元の地殼構造探査やマルチナロービームによる海底地 形調査, 自律式ロボットAUVやしんかい6500による潜航 調査など, 広域の基礎デー夕は既にかなり揃っていた。と
いうのも，1995年1月の兵庫県南部地震を受けて, 1996 年 10 月から「海底下深部構造フロンティア」プロジェクト が，JAMSTEC内に立ち上がり，1995年に就航した深海調 査研究船「かいれい」を主力船とした海底下の調査がスター トしていた。「かいれい」を用いて, 南海トラフや日本海 溝をターゲットに, 海底下 $20 \mathrm{~km}$ 深度程度の断層のイメー ジングを目指し，組織的に広域地震探査が展開された（現 在「地震津波海域観測研究開発センター」へと組織拡大改 編されている)。海溝域を縦横に走る測線からは，沈み达 むプレート上部が見えていた（例えば，Park et al., 1999； Kodaira et al., 2002). いよいよ 2002 年の地震発生帯を掘削 するという計画を前に，「かいれい」による 2 次元の広域探 査結果は頻繁に参照され，掘削点選定に用いられた。掘削 に先立ち, 安全評価および付加体の理解のため, $5 \mathrm{~km}$ 四方 の浅部を重点的にターゲットとした高解像度の地殼構造探 査デー夕を得るため, 2003 年には石油業界仕様の 2 次元地 震波構造探査が行われた(Taira et al., 2005). この調査では, 浅部を特に詳細にサーベイするために商業用調査船を用い た，その後 2006 年 5 月，物理探査船 M/V Nordic Explore 号 を用いて高精度 3 次元地震探査も行うことになった（Uraki et al., 2009). 3 次元探査に当たっては，周辺海域の漁業関 係者と気象海象条件などを考慮した漁業調整が行われた。 幸い調査海域は航路から外れているため航行船舶は少な く, スムーズな漁業調整がなされたが, 対象海域の南部は, 強潮流の黑潮の通り道であり, $4.5 \mathrm{~km}$ 長のストリーマーケー ブルの曳航，データ取得に影響した。データ処理は，波浪 ノイズや多重反射波の抑制といった基本処理に重点が置か れた。結果として得られたサイズミックキューブは，浅層 部の地質状況をよく表し, 沈み込む海洋プレートの上面も 明瞭に可視化されていた（第6図: Moore et al., 2007; 朴ほ か, 2008; Uraki et al., 2009; Moore et al., 2009). そして, こ の 2006 年の記録を元に, 最終的な南海掘削の選定がなさ

第 1 表 掘削事前調査項目

\begin{tabular}{|c|c|c|}
\hline 調査項目 & 測定機器類 & 目的 \\
\hline 海底地形精査 & $\begin{array}{l}\text { 曳 航・AUV (Autonomous Underwater } \\
\text { Vehicle)) 潜航等によるサイドスキャン音 } \\
\text { 響画像, サブボトムプロファイル }\end{array}$ & $\begin{array}{l}\text { ウェルヘッド設置地点選定のため } \\
\text { の微地形および茋質の適合性評価 }\end{array}$ \\
\hline 浅部, 表層堆積調査 & $\begin{array}{l}\text { HR3D MCS (High Resolution } 3 \text { Dimensional } \\
\text { Multi-Channel Seismic) }\end{array}$ & $\begin{array}{l}\text { 浅層ガス, 帯水層, 断層分布等の } \\
\text { 浅層ハザード評価 }\end{array}$ \\
\hline 浅部, 表層堆積調査 & 40m ピストンコア & $\begin{array}{l}\text { ライザートップホール（ウェルヘッ } \\
\text { ド, 36”コンダクターパイプおよ } \\
\text { び20”ケーシング）構築のための } \\
\text { 浅層地層強度評価 }\end{array}$ \\
\hline 速度構造調査 & OBS 詳細速度構造 & $\begin{array}{l}\text { 作井 (地層圧予測, ケーシング計画, } \\
\text { 泥水計画, 掘削ツール選定, 工程 } \\
\text { 計画等) のための地質評価・深層 } \\
\text { ハザード評価 }\end{array}$ \\
\hline 潮流，海流調査 & ADCP (Acoustic Doppler Current Profiler) & 掘削サイト周辺の強潮流の調査 \\
\hline
\end{tabular}


れた．特に「ちきゅう」の国際運航第 1 回目となる第 314 次航海では, 南海トラフを横切る全長 $60 \mathrm{~km}$ のランセク 卜に6箇所の孔が掘られ，掘削同時検層（ロギングまたは LWD: Logging-While-Drilling) という物理探査法により, 垂直方向の速度構造データが取得された，前出の 3 次元地 殼構造探查で得られたデー夕と比較され, 調和的な結果を 得ることができた（Tobin et al.,2009）.

その後, サイト 0002 はさらに媣く掘り, 長期孔内計 測機器を設置し, 海底面に敷設する地震計ネットワークシ ステムと結ぶことが決まった。 サイトC0002は, 2010年 6 月の第 326 次航海で海底面に深堀用のウェルヘッドが設置 され，10月には海底からの深さ $1000 \mathrm{~m}$ に長期孔内計測器 が設置された (Expedition 332 Scientists, 2011)。な扮長期 孔内計測機器は, 南海トラフの直行方向の動きがすぐに把 握できるよう，さらに海側の $\mathrm{C} 0010$ （2016年 4月の第 365 次航海にて設置済み）とC0006（2018年1２月予定）で 計画されている.

いよいよ南海トラフの最終段階では, サイトC0002の さらに媣堀を狙う。その事前調查資料となる2006年に得 られた 3 次元地震波構造断面図では, サイト C0002の海底 下深度 $3000 \mathrm{~m}$ 以深の複雑な地質構造を明瞭には可視化で きなかった。 2013年1月に行われた第348次航海では, 切 り立つような断層崖からの削りカスが孔底を埋めて, 計画 通りに掘り進むことが困難となった。 ちょうど 3 次元構造 断面図では, 速度構造が不明瞭な箇所にかかっていた。さ らなる超深度を狙うためには, より正確な速度構造や密度 構造が必要となり，2006年の 3 次元構造探査デー夕を再度 見直すことが議論された。最新の波形解析手法を適用した 再解析を施し, 狙う深度の情報の精度を上げようと試みら れた (Shiraishi et al., 2016)。この解析結果を見ながら, 前 弧域の海底下にある分岐断層を目指す掘削計画が練られて いる，それまでの記録とは明らかに異なる強い反射断面が $5400 \mathrm{~m}$ の深さに現れている，本掘削計画では，その強反射 面を詳細に調査するために，2018年10月から第358 次航 海として, 下記の J-DESC ウェブサイトより乗船研究者募 集段階となっている (2017年 12 月現在).

http://www.j-desc.org/358-nantroseize-deep-riser-drilling/ 事前調査データとしての一連の地震探査データは, 「ち きゅう」による科学掘削に必要な基礎資料となっただけで

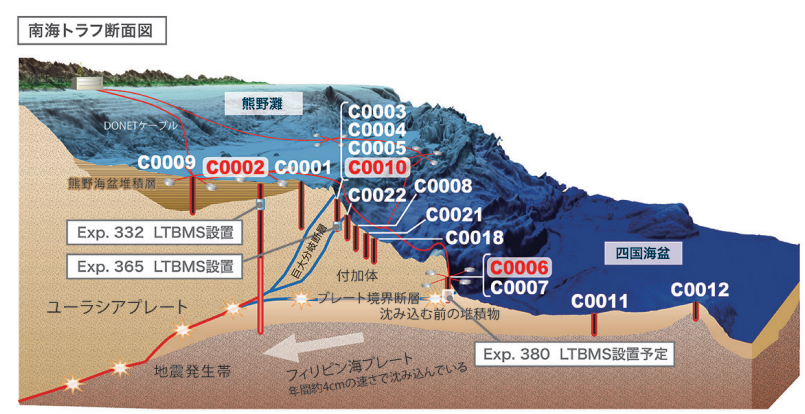

第6図 南海トラフの 3 次元地凯構造図
なく，当該海域の研究にも貴重な情報を提供することと なった，科学掘削の分野で 3 次元探査例は少ないため, 探 査仕様については，石油業界の例に学んだ，米国テキサス 大学のサイトに今までに行われた学術目的での 3 次元地震 波探查情報がまとめて揭載されている（参照サイト：http:// www-udc.ig.utexas.edu/sdc/)。このサイトでは, 1987年にコ スタリカ沖で得られた 3 次元探査から 2013年のメキシコ湾 での11例を時系列に並べて紹介しており，必要なデー夕 が入手できるようになっている，日本周辺も，1999年の南 海トラフ室戸沖と 2006 年熊野灘の 2 例がリストアップされ ている. 個々のサイトからは, 探査の基礎情報始めナビゲー ションデータ, 地震波のフィールドデータから一次処理済 みのSEGY データ，関連論文など，ユーザー登録をすれば 誰でもダウンロードできるよう公開されている.

掘削事前調査に必要な項目は, 地震波による地殼構造探 查以外にも, 数多く存在する (第 1 表)。広域調査の後, 海 底地形精查, 海底カメラ, 海流, 潮流, ジオテクコア (地 盤安定性吟味用) 強度試験用試料の取得と 2 軸 3 軸圧縮試 験といった室内実験などが要求される。これら必要充分な データが揃っていなければ, 掘削安全委員会での議論の遡 上に乗らず，掘削孔の太さや深度や泥水選択などの掘削計 画が立てられない。

\section{5. 地質評価のための掘削時のデータ取得}

掘削が実現し, 海底下を掘り始めると, 様々な地下情報 が得られるようになる。コア試料だけではなく, 物理検層 デー夕, 泥水検層, カッティングス, ガスモニタリングデー 夕, 掘削時パラメータである温度, 圧力, 掘進率, ビット トルク, ビット回転数, 泥水比重, 泥水流量なども, 掘削 時の重要タスクである地質評価に貢献するデータとなる。 実際の海底下の地質サンプルであるコア試料と比較する と, 検層デー夕は, 連続して深度方向に高精度で得られる 孔内状況把握のためのデジタルデータである. その種類も, 第 2 表に示すように多岐に亘り, 掘削安全性の指標として, また研究目的に応じて, 複数の検層デー夕を選択し, 統合 解釈することにより，地下情報の推定に役立つ．観測対 象範囲や必要なデー夕解像度 $\left(10^{-2} \sim 10 \mathrm{~m}\right)$ に応じて検層 ツールを選択する。検層は, コア試料 $\left(10^{-2} \mathrm{~m}\right)$ とサイズミッ ク（10〜100m）を結ぶスケールをカバーする地球内部の 聴診器の役割を持つ. 特に海底下の微視〜巨視的解棌をす る「コア・ロギング・サイズミック統合化」には，連続し て取得できる検層は欠かせない，物理検層の手法は，掘削 孔がすでにあり，ワイヤラインの先端部にセンサーパーツ を付けて，孔底から引き揚げながら測定するタイプ（ワイ ヤライン検層）とセンサー部分をドリルパイプの先端に埋 め込久, 掘削と同時に物理測定ができるタイプ（掘削同時 検層）と大きく2種類に分かれる (第7図). 得られた検層 データの深度方向のプロット例を示す (第8図). 検層デー 夕を用いた地質評価や解釈については, 別稿にて紹介した 
第 2 表 検層の種類と目的

\begin{tabular}{|c|c|}
\hline 検層項目 & 目的 \\
\hline $\begin{array}{l}\text { キャリパー 孔径) } \\
\text { 温度 (泥水) } \\
\text { 泥水比抵抗 } \\
\text { 泥水循環の温度 }\end{array}$ & $\begin{array}{l}\text { 計測データの環境補正. } \\
\text { 孔のサイズ, 拡張していな } \\
\text { いか, 崩落がないか, 温度 } \\
\text { 異常がないか, 熱水湧出や } \\
\text { ガスの吹き出しがないか, } \\
\text { 断層の有無, など, 掘削時 } \\
\text { の内内環境情報を得る. }\end{array}$ \\
\hline $\begin{array}{l}\text { 自然ガンマ線, } \\
\text { ガンマ線スペクトル } \\
\text { 光電子ファクター, 電気 } \\
\text { 比抵抗 } \\
\text { 密度, 孔隙率, 音波検層 }\end{array}$ & $\begin{array}{l}\text { 地層, 岩相区分に用いる連 } \\
\text { 続的な物性值の変動を知る }\end{array}$ \\
\hline $\begin{array}{l}\text { 比抵抗イメージ, 超音波 } \\
\text { イメージ } \\
\text { ボアホールカメラ } \\
\text { チェックショット, } \\
\text { VSP (Vertical Seismic } \\
\text { Profiling) } \\
\text { サイドウォールコア } \\
\text { MDT (流体サンプル, } \\
\text { Modular Formation } \\
\text { Dynamic Tester) }\end{array}$ & $\begin{array}{l}\text { 孔壁地層の可視化画像. 亀 } \\
\text { 裂や断層の識別. } \\
\text { 地層の走向・傾斜. } \\
\text { 深度方向の変化にともなう } \\
\text { 弾性波速度情報を得る. } \\
\text { 原位㯰の壁地層や地層水 } \\
\text { のサンプリング, および原 } \\
\text { 位置のテスティング. }\end{array}$ \\
\hline
\end{tabular}

い.また，掘削作業時に孔内を循環させる流体を使った物 理計測を泥水検層といい, 効率的な掘削作業のため, 孔内 の安定化や洗浄を目的とする. 泥水循環とともに船上へ上 がってくるガスのモニタリングやカッディングスの形状分 析も, 重要な地質評価指標であり, 科学掘削に欠かせぬ項 目である (第 9 図)，泥水検層は，孔内に関する種々のデー
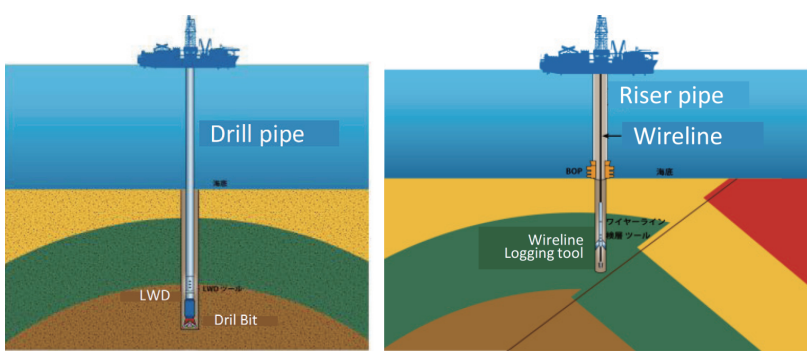

第7図＼cjkstart掘削同時検層とワイヤラインロギングの模式図

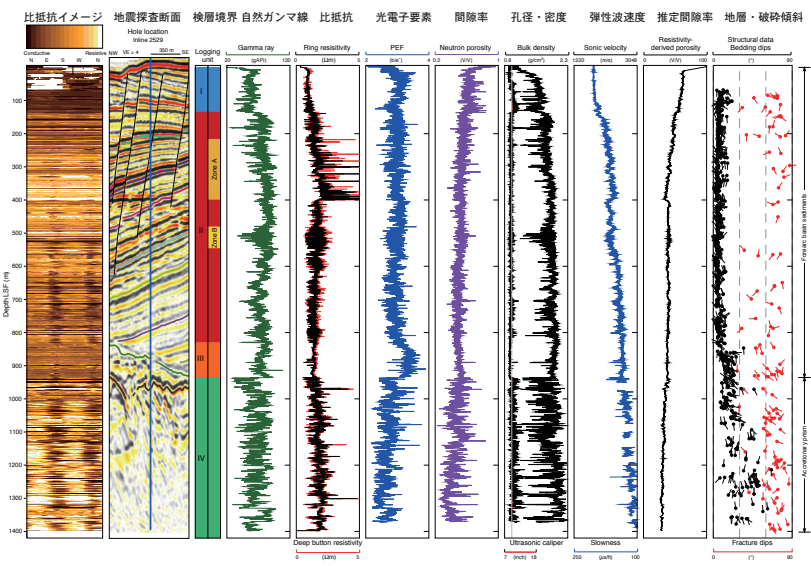

第8図 南海トラフのC0002サイトでの掘削同時検層で得られた 深度方向のロギングデー夕例（海底下 $1400 \mathrm{~m}$ まで）

夕を掘削作業と並行して連続的に収集・分析し, 安全な掘 削作業を進め, 地質状況の把握をする。そちらについても， 機を改めて紹介したい.

ここでは，科学支援における検層サービスについて触れ ておく.IODP プロポーザル提出時の必須記載項目として, その海域の既存事前調査デー夕および検層種目の有無，そ

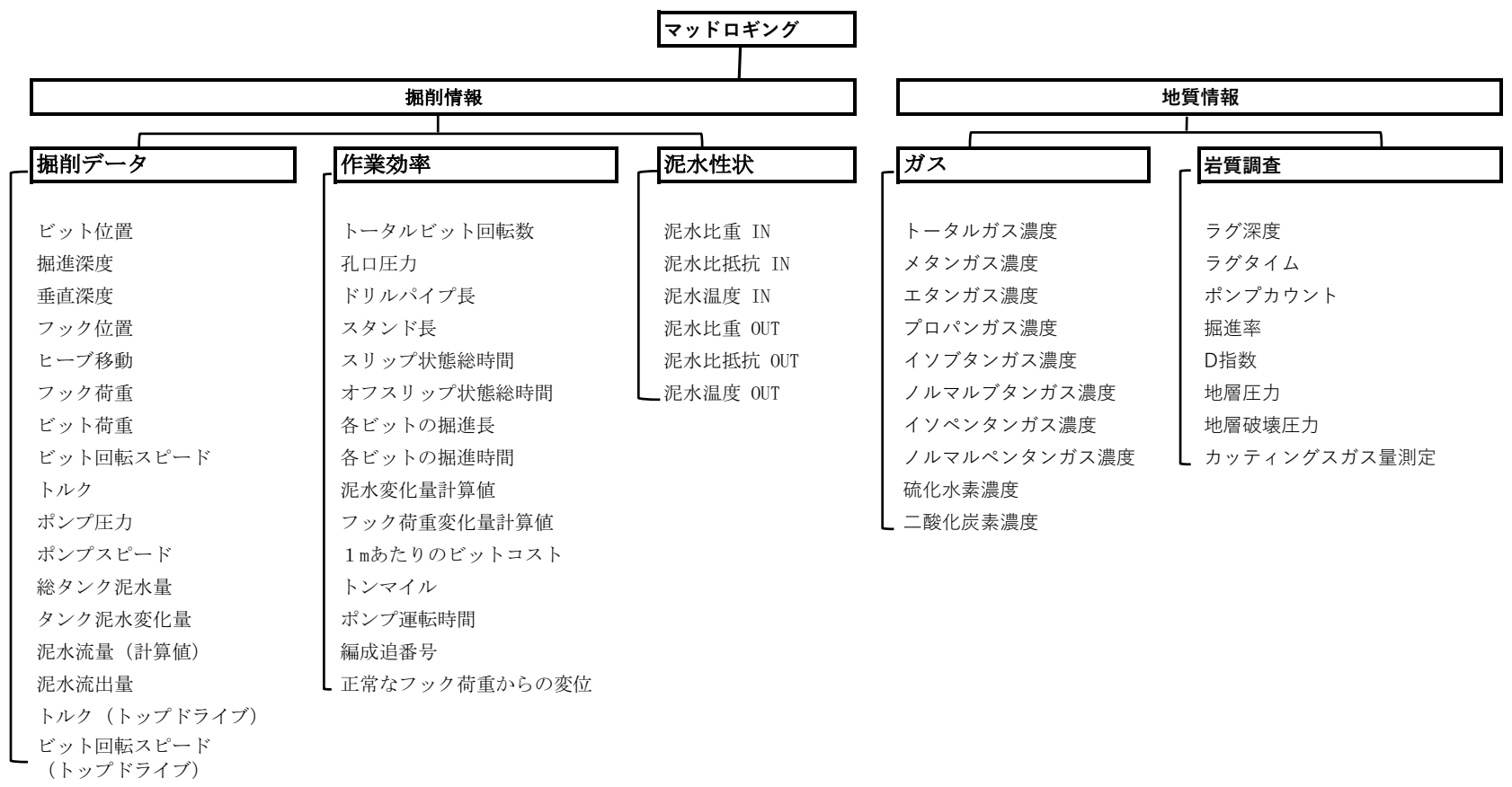


して航海計画内にどのような検層種目を希望するかの記載 がある，検層費用は高額になるため, 科学目的に応じて 最適な選択ができるようなアドバイスが実施機関である CDEXには求められる。 CDEX 地質評価グループには，検 層担当者 (LSS: Logging Staff Scientist) が, 必要十分なツー ルの選択ができるようスペックの説明，過去の資料の提 供, 検層業者とのやり取りを担当する。検層会社には, 最 適なツールの選択に必要な情報提供, 使用するツールの輸 出入手続き, 見積もりの依頼を行う. 実際の検層作業中に は，エンジニアによるツールの検査の立ち会いからデータ 取得作業の確認, リアルタイムデータ, ログプロットとい う船上で得られる検層記録の確認と受け渡し, データの品 質管理，乗船研究者への一次データの配信，さらに高次の 解析, 乗船レポート作成の補助, ウェブサイトへ掲載する データ整理, 更新作業など, 時系列順に生じる. IODP プ ロポーザルのスタートから実施, 終了後のモラトリアム期 間開け, 航海終了 2 力年後の最終レポート提出までの複数 年間のプロポーザル熟成・進化過程とともに様々な研究者 へのサポートサービスが生じる.

\section{6. コア・ロギング・サイズミック統合化}

「ちきゅう」を取り巻く事前調査から掘削データまでの 様々なデー夕は 1000 種以上にも及び，その観測レンジは, $10^{-2} \sim 10^{2} \mathrm{~m}$ の 4 枌にわたる. 得られる膨大なデー夕は,「コ ア・ロギング・サイズミック統合化」により海底下の微視 〜巨視的解釈に利用することができる。事前調査として, まずは掘削点をカバーするよう幅 $12 \mathrm{~km} \times$ 長さ $56 \mathrm{~km}$ 範囲 の 3 次元地震探査データを得, 3D PSDM (Pre-Stack Depth Migration) 処理が施され, 任意の深度断面図がイメージさ れた (Moore et al., 2009). この図に第314 次航海の掘削点 とロギングデータを投影する。第 315,316 次航海で得られ たコア試料の物理計測值のプロットも重ねて表示すると, 深度と時間軸に物理情報が加わる. 独立なデータセットと しては実現しなかった地下をビジブルに統合化すること は,「ちきゅう」データベースの構築によって初めて実現 可能となった.

ここでは，事例研究例を紹介する. Strasser et al. (2009) は, 付加体の深度断面にコア分析で得られた時間軸を入れ, 繰り返し地震で有名な南海トラフの履歴を世界で初めて示 した。 またYamada et al.(2011) は, LWDで得られた孔壁 の 360 度方向の比抵抗值の展開図と 3 次元地震探査断面図 を表示し, 断層面の走向, 傾斜方向, 地層境界情報を入れ, 両者の解釈の比較を試みている。比抵抗イメージからは, 孔壁の圧縮性破壊（ボアホールブレイクアウト）を見出し, ヒビ状の局所的崩壊の方向や幅から, 地震 - 地殼変動後の 地層内の応力状態が定量的に推定できる. 異なるスケール や分解能のデータを一緒に表示し, 相違点を明らかにしつ つ相補的に解釈に用いる可能性を示している（Yamada $e t$ al., 2011).
Sugihara et al. (2014) は, 南海トラフ熊野灘のメガスプレ イの直上サイト C0002の温度プロファイルを過去に得られ たあらゆる掘削データを用いて吟味している。2007年の 第 314 次から $315,326,332,338,348$ の 6 航海に渡り, 海底 下 $3,058 \mathrm{~m}$ という世界最深度に到達するまでの段階で得ら れたコア試料, 検層, 泥水検層, ガス分析, 長期孔内計測 器を利用している。サイト 0002 は, 世界一データの豊富 な孔である。この論文での温度推定值をべースとして，さ らにメガスプレイ断層境界の 5,200m を目指し，2018年 10 月からの第 358 次航海計画が立てられている.

こうした「コア・ログ・サイズミック統合化」の実現の ためには, 航海後のデー夕品質管理, データベース登録, そして的確なデー夕公開である。杉原（2017）は，より幅 広い利用者を対象に掘削パラメータの利用価值についても 紹介している，掘削パラメータは，運用に欠かせない掘削 安全性の示準として, リアルタイムに取得されており, 運 用従事者や掘削技術者の詰めるオフィス内の大画面に常時 プロットされ，孔内状況が瞬時に把握できるようになって いる。データは 1 秒間隔で共有フォルダーに自動保存され ている.

上記のデー夕は，航海終了後にデータベースに保存更新 され，一定期間後には公開されている。掘削パラメータに ついては, 現在データベース公開はしていないが, 近年, 掘削パラメータの利用価值が高まり, 研究者からの要望が 増えていることから，リクエストに応じてフィールドデー 夕を提供している。「ちきゅう」沖縄熱水活動域での掘削 では，LWDと掘削パラメータを駆使して孔内状況を把握 する試みも世界で初めて行われている（濱田ほか，2016； 真田ほか, 2017).

\section{7. 航海データサイト・機構ファシリティの公開 サイト}

ここでは，前出の事例のような事前調査や検層データと いった掘削を取り巻く海洋データのオープンサイトの紹 介をしたい. 海洋研究開発機構（以下, JAMSTEC) では, 2017 年 11 月現在では，9隻の海洋調査船「かいれい」「よ こすか」「みらい」「なつしま」「かいよう」「かいめい」「新 青丸」「白鳳丸」そして「ちきゅう」のデータオープンサ イトとなっている。この中で「なつしま」「かいよう」の 2 船はすでにリタイヤしているが, 全部で 1735 航海分 (2018 年1月現在）のデータが, ウェブ登録すれば, ダウンロー ドできる。データの種類は, 航海レポート, サマリー（日 英), 航跡デー夕, 海底地形, 重力, 地磁気とそれらの解 析に必要な補正デー夕などである。調査概要を迅速に公表 するため, 終了後 2 ケを経過した調査航海については, クルーズサマリーや航跡といった速報值をウェブ公開して いる (http://www.godac.jamstec.go.jp/mapsearch/j/). 測深デー 夕や重力・地磁気といった航走時データについては, 公開 猶予期間が経過し，品質管理および公開準備が整ったもの 
から同航海のサイトで公開している．JAMSTEC 航海・潜 航データ検索システム DARWINについては, 下記のURL を参照されたい.

http://www.godac.jamstec.go.jp/darwin/j

http://www.godac.jamstec.go.jp/darwin/datatree/j

上記の「ちきゅう」の各航海サイトからは,さらに詳細な 航海内容や調査項目を確認することができる。

「ちきゅう」のIODP 航海に関しては, 専用サイト http:// sio7.jamstec.go.jp/が立てられている。このデータサイトか らは, XCTコアの元データ, 画像イメージ, 個々のコア 分析值の全て, 時間軸および深度軸の検層データ, LWD 比抵抗画像データなど，1年間のモラトリアム以降は，す ベてのデータがダウンロードできる，上記のDARWINサ イトの「ちきゅう」航海からリンクが張られている。「ち きゅう」紹介サイトからは, 掘削航海計画書, 速報成果報 告書, 2 力年の期限後の航海報告書が閲覧可能である。「ち きゅう」デー夕は多岐にわたるため, ウェブ公開されてい ない掘削パラメータデータも，リクエストベースで対応可 能である。

\section{8. おわりに}

本稿では，主として，「ちきゅう」の事前調査および掘 削時に得られる検層・物理探査データとそのサイト情報の 紹介を行った。就航 12 年目を迎えた「ちきゅう」は, スタッ フのスキルも向上し, 効率的で質の高いオペレーションが 行えるようになった。 今後は, J-DESCを通して, 研究者 コミュニティに「ちきゅう」の施設・設備を宣伝し, 研究 成果をさらに広く紹介してきたい，多くの研究者に利用し てもらえるよう, 掘削提案のフローについても, さらに明 確化し, プロポーザルの質・量ともに向上して日本の掘削 科学におけるプレゼンスをあげていきたい.

\section{文献}

Chikyu IODP 航海で取得されたデータサイト：

http://sio7.jamstec.go.jp/

Expedition 332 Scientists (2011) Expedition 332 summary.

In Kopf, A., Araki, E., Toczko, S., and the Expedition 332

Scientists, Proc. IODP, 332: Tokyo (Integrated Ocean

Drilling Program Management International, Inc.).

doi:10.2204/iodp.proc.332.101.2011.

濱田洋平 · 斎藤実篤 ·真田佳典ほか（2016）海底下高温流 体の温度と流体量の推定 : 掘削同時検層と掘削パラメー タからのアプローチ. 日本地球惑星科学連合 2016 年大 会, MIS16-04.

JAMSTEC 航海・潜航データ検索システム DARWIN につ いて : http://www.godac.jamstec.go.jp/darwin/j

JAMSTEC 航海データポータルサイトについて : http://www.godac.jamstec.go.jp/dataportal/viewer.htm

Kodaira, S., Kurashimo, E., Park, J. -O., Takahashi, N., Nakanishi,
A., Miura, S., Iwasaki, T., Hirata, N., Ito, K. and Kaneda Y. (2002) Structural factors controlling the rupture process of a megathrust earthquake at the Nankai trough seismogenic zone. Geophys. J. Int., vol. 149, issue 3, pp. 815-835.

doi:10.1046/j.1365-246X. 2002.01691.x

Moore, G.F., Bangs, N. L. Taira, A., Kuramoto, S., Pangborn, E. and Tobin, H. (2007) Three-dimensional splay fault geometry and implications for tsunami generation. Science, vol. 318, issue 5853, pp. 1128-1131. doi: 10.1126/science.1147195

Moore, G.F., Park, J. -O., Bangs, N. J., Gulick, S. P., Tobin, H., Nakamura, Y., Sato, S., Tsuji, T., Yoro, T., Tanaka, T., Uraki, S., Kido, Y., Sanada, Y., Kuramoto, S. and Taira, A. (2009) Structural and seismic stratigraphic framework of the NanTroSEIZE Stage 1 transect. In Kinoshita, M., Tobin, H. J., Ashi, J., Kimura, G., Lallemant, S., Screaton, E. J., Curewitz, D., Masago, H., Moe, K. T. and the Expedition 314/315/316 Scientists, Proc. IODP, 314/315/316: Washington, DC (Integrated Ocean Drilling Program Management International, Inc.).

doi: 10.2204/iodp.proc.314315316.102.2009

日本掘削科学コンソーシアム (Japan Drilling Earth Science Consortium: J-DESC ウェブサイト : http://www.jdesc) 乗船募 集: http://www.j-desc.org/358-nantroseize-deep-riser-drilling/ Park, J.-O., Tsuru, T., Kaneda, Y., Kono, Y., Kodaira, S., Takahashi N. and Kinoshita, H. (1999) A subducting seamount beneath the Nankai accretionary prism off Shikoku, southwestern Japan. Geophysical Research Letters, vol. 26, no. 7, pp.931-934. doi: 10.1029/1999GL900134

朴進午 · 鶴哲郎 · 野徹雄 · 瀧渾薰 · 佐藤壮 · 金田義行 (2008) 紀伊半島南東沖南海トラフでの高分解能 3 次元反射法地 震探査と重合前深度マイグレーション処理. 物理探査, vol. 61, no. 3, pp.231-241. doi:10.3124/segj.61.231.

真田佳典・山田泰広ほか（2017）沖縄伊是名海穴の海底熱 水鉱床に损ける自然ガンマ線と温度と圧力検層データの 考察. 日本地球惑星科学連合 2017 年大会, MIS22-P02.

Shiraishi, K., Kinoshita, M., Moore, G., Sanada, Y., Yamada, Y., Kimura, G. (2016) Improvement of 3D MCS data processing by advanced technology in Nankai trough. JpGU Meeting, p. S-SS02.

Strasser, M., Moore, G. F., Kimura, G., Kitamura, Y., Kopf, A. J., Lallemant, S., Park, J. -O., Screaton, E. J., Su, X., Underwood, M. B. and Zhao, X. (2009) Origin and evolution of a splay fault in the Nankai accretionary wedge. Nature Geoscience, vol. 2 (9), pp. 648-652. doi:10.1038/ngeo609.

Sugihara, T., Kinoshita, M., Araki, E., Kimura, T., Kyo, M., Namba, Y., Kido, Y., Sanada, Y. and Moe, K. T. (2014) Re-evaluation of temperature at the up dip limit of locked portion of Nankai megasplay inferred from IODP Site C0002 temperature observatory. Earth, Planets and Space, 66:107. 
http://www.earth-planets-space.com/content/66/1/107

https://doi.org/10.1186/1880-5981-66-107

杉原孝充 ·井上朝哉・木戸ゆかり - 青池寛 - 真田佳典 - 石 原浩・藤井毅・三上博之 (2017) 地球深部探査船「ちきゅう」 での掘削パラメータデータの取得と利用：孔内科学デー 夕との比較と現状. 日本地球惑星科学連合大会 2017 年 大会, MIS22-03.

Summary of 3-D Academic Seismic Portal site at UTIG: http://www-udc.ig.utexas.edu/sdc/

Taira, A., Curewitz, D. et al. (2005) Nankai Trough Seismogenic Zone Site Survey: Kumano Basin Seismic Survey, Philippine Sea, Offshore Kii Peninsula, Japan. CDEX Technical Report, vol. 1, 64pp. http://sio7.jamstec.go.jp/publication

Tobin, H., Kinoshita, M., Moe, K. T. and the Expedition 314 Scientists (2009) Expedition 314 summary. In Kinoshita, M., Tobin, H., Ashi, J., Kimura, G., Lallemant, S., Screaton, E. J., Curewitz, D., Masago, H., Moe, K. T. and the Expedition
314/315/316 Scientists, Proc.IODP 314/315/316: Washington, DC (Integrated Ocean Drilling Program Management International, Inc.)

doi:10.2204/iodp.proc.314315316.111.2009

Uraki, S., Kido, Y., Sanada, Y., Kuramoto, S., Okano, T., Saga, H., Park, J. -O., Moore, G. and Taira, A. (2009) Kumano-nada 3D seismic data acquisition and processing. Butsuri-Tansa (Geophys. Explor.) vol. 62, no. 2, pp. 277-288. doi:10.3124/ segj.62.277

Yamada, Y., McNeill, L., Moore, J. C. and Nakamura, Y. (2011) Structural styles across the Nankai accretionary prism revealed from LWD borehole images and their correlation with seismic profile and core data: results from NanTroSEIZE Stage 1 expeditions. Geochem. Geophys. Geosyst., vol. 12, issue. 7 .

doi:10.1029/2010GC003365.

\section{要 旨}

\section{地球深部探査船「ちきゅう」の物理探査・地質データの活用と今後の期待}

\section{木戸ゆかり・杉原孝充・真田佳典}

地球深部探査船「ちきゅう」は，構想から 10 年を経て建造され，2005年 7 月 29 日にJAMSTEC（現在の国立研究開 発法人 海洋研究開発機構) に引き渡された。2 年間の慣熟航海を経て，2007年 10 月からは，IODP（国際深海科学掘 削計画）の主力船の一隻として, 日本周辺の複数箇所の科学掘削に実績を残してきた。本技術報告では, 情報地質学 分野に利用価值が高いと思われる「ちきゅう」の科学掘削の事前調査, 物理探査や掘削時に得られる地質情報につい て紹介し，合わせて今後の方向性なども示したい.

キーワード：地球深部探査船「ちきゅう」, IODP, 事前調査, 地殼構造探査, 検層 